\title{
Designing and Developing of E-Commerce Website for Unused New Goods
} Shopping

\author{
Abeer S. Alkhalfan, Zainab W. Altheeb, Noor A. Alshamsi, Heba W. Alothman, Ibrahim Almarashdeh, \\ Muneerah Alshabanah, Daniah Alrajhi And Mutasem K. Alsmadi
}

Department of Management Information Systems, College of Applied Studies and Community Service, Imam Abdulrahman Bin Faisal University, Dammam, Saudi Arabia

\begin{abstract}
According to the fast-changing business environment nowadays, we have to be more effective and faster in responding to customers' needs to make them able to access products instantly. This can be done by designing an E-commerce web website for unused goods, which sells various fashions and goods to the customers. To implement an online shopping website, a virtual store on the Internet is needed which allows customers to seek products and select them from a catalog. The customer needs to fill some fields to order a specific product. The purpose of this paper is designing and implementation of the website of unused goods, which sells various fashions and goods to the customers, the good that will be for sale on the website are new unused goods which the customer couldn't return to the store they buy from to any reason. The proposed system was developed using the Unified Modeling Language (UML), ASP.NET and Access.
\end{abstract}

Keywords : Online Shopping System, Unused goods and E-commerce Website.

\section{INTRODUCTION}

Electronic commerce (E-commerce) is the selling and buying of services and goods, or conducting data or funds, through an electronic network, mainly the internet. During the era of technology, e-commerce is gaining attention as a used and accepted business paradigm [1, 2]. These commercial transactions happen either as business-to-consumer (B2C), business-to-business (B2B), consumer-to-business (C2B) or consumer-to-consumer (C2C). The terms ebusiness and e-commerce can be interchangeably used. Also, E-tail term is sometimes used when referring to online shopping transactional processes. Increasingly business houses are employing websites that provide the functionality to perform over the web commercial transactions. It is realistic to say that the shopping process on the web will become a commonplace.

Since the emergence of the World Wide Web (WWW), vendors can easily sell their products to different kinds of people over the internet. Many people prefer online shopping because of its different kinds of convenience. They can find a specific product by searching various online stores which are less time consuming and tedious process rather than searching this product in various stores in the market [3].

The most common online retailing companies are Amazon.com, Alibaba, and eBay. The success of retail is no more about physical stores, this is due to the increase in stores that offers online shopping for consumers $[3,4]$. 


\section{RELATED WORKS}

Retailbd is e-commerce online website, people can buy from it limited items such as wallets, watches, bag sunglasses, and belts [3]. There are choices for women and men. You can choose your category. The website uses high-quality photos so the customer can get details about the products easily. Figure 1: Home page of retailbd.com.
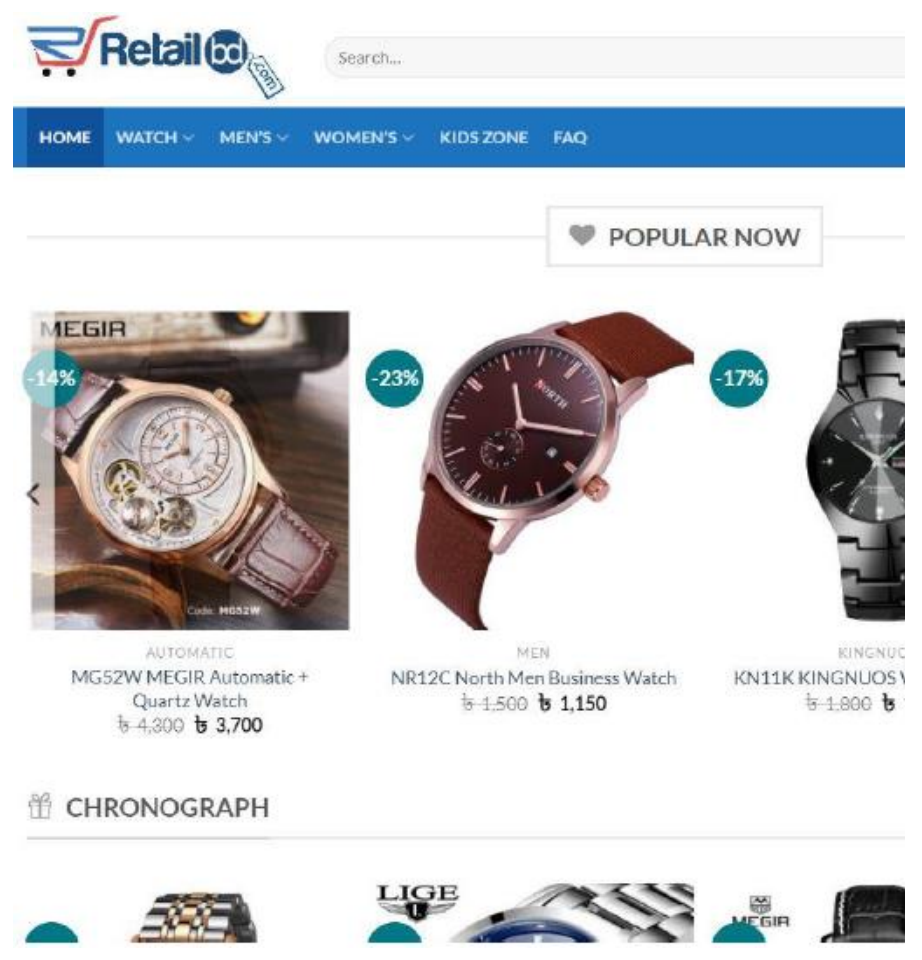

Figure 1 : Home page of retailbd.com

An Online Shopping is a web application for lifestyle e-commerce which has been developed by [5], the proposed web application retails various fashion and lifestyle products (Men's Wear). Moreover; the proposed application enables the user to view available products and to purchase any of them immediately using payment through PayPal processor (Instant Pay) and order anything using Cash on Delivery. Figure 2: the proposed web application home page.

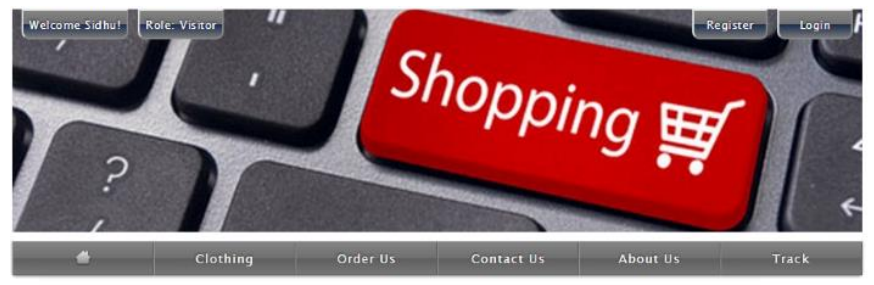

Online Shopping (Graduate Final Project) - Governors State University

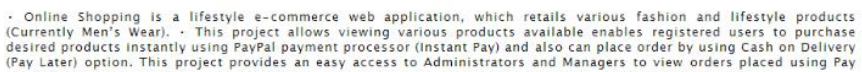

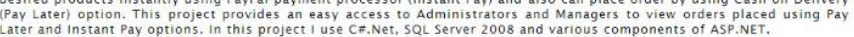

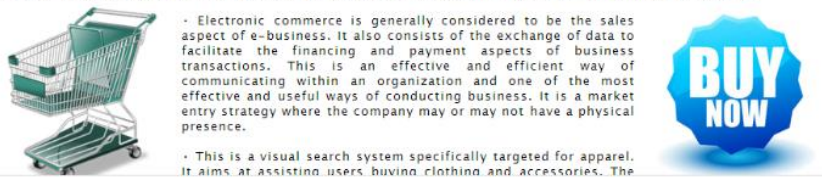

Figure 2 : Home page of the proposed web application. Rabbi and Islam in [3] proposed an online ECOMMERCE site. This proposed site is used for online shopping and the user can check ordered items online and the delivery is free to the user address. It is a good interaction source between the shopkeepers and the user. Figure 3: The proposed web site home page.

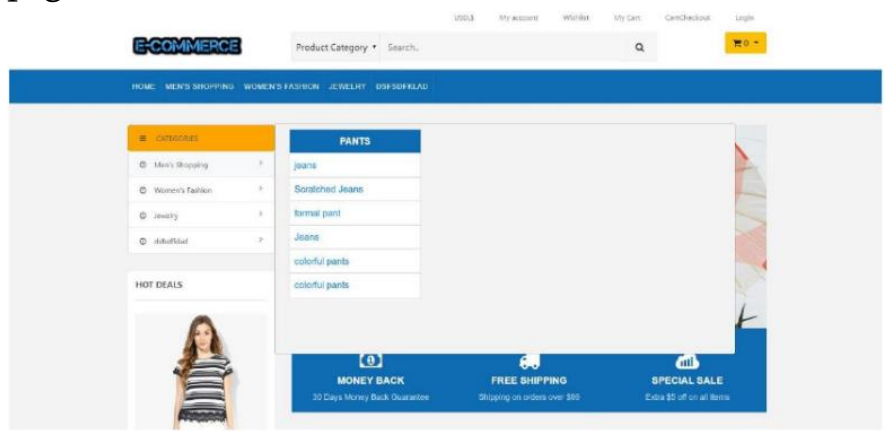

Figure 3: Home page of the proposed web site.

The revolution of technology influenced everything [6-83], even the methods of e-commerce and online shopping. Today, the Artificial Intelligence (AI) algorithms use is expansive, mainly in providing solutions to challenging problems including information retrieval [53], image segmentation [7] and Healthcare Monitoring system [46, 57]. Accordingly, utilizing web technology and AI algorithms, many researchers have created as well as implemented E-commerce and online shopping applications systems to solve issues in various fields. 


\section{METHODOLOGY}

The UML is the standard language for specifying, constructing, documenting and visualizing all the software system artifacts as well as for other nonsoftware systems and business modeling. The UML denotes a group of best engineering practices that have demonstrated success in complex and large systems modeling [84-88].

The application architects and programmers, using UML, can make a project blueprint, which makes the actual process of software development easier.

\subsection{Use Case Diagram}

Use case diagram is a type of UML diagram which allows the modeling of system functions in addition to the actors which interact with the functions $[19,87$, 89, 90]. In the proposed work the actors are the System Administrator, User, and delivery. Figure 4 shows the use case diagram for the proposed system.

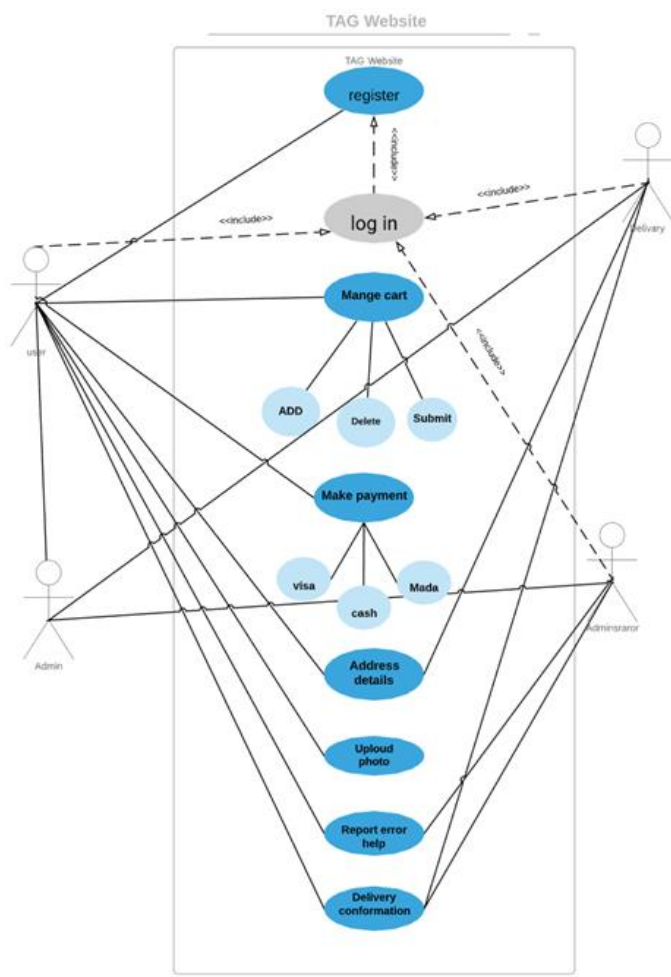

Figure 4: Use Case Diagram of the proposed system.

\subsection{Functional Decomposition Diagram}

The functional decomposition diagram (FDD) is defined as a top-down representation of process or function. The business analyst uses a functional development diagram for showing business function and break these functions into lower-level operations and processes $[19,87,89,90]$. Figure 5 shows the FDD for the proposed system.

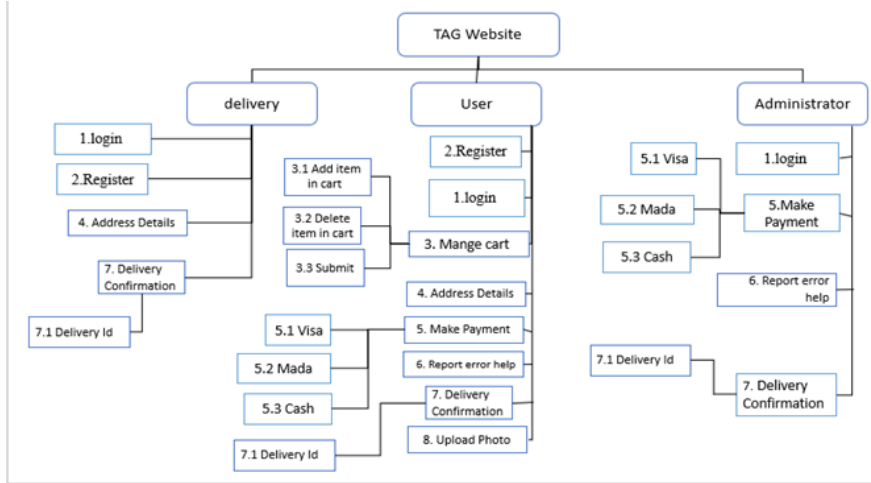

Figure 5 shows the FDD for the proposed system.

\subsection{Entity-Relationship (ER) Diagram}

ER diagram shows the entity set relationships stored in a database. In other words, ER diagrams assist you to explain the logical structure of databases. ER Diagram contains many symbols that are specialized, and its denotations make this model unique [44, 45, 54, 55, 91]. The purpose of the ER Diagram is to denote the infrastructure of the entity framework. Figure 6 demonstrates the proposed system ER diagram. 


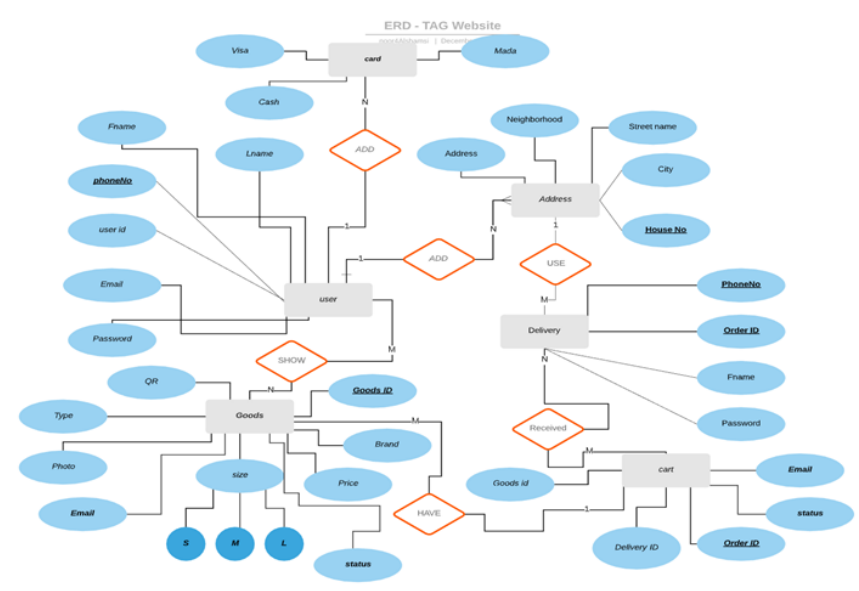

Figure 6 shows the ER diagram for the proposed system.

\section{INTERFACE DESIGN}

User interface design mostly denotes the elements' visual layout which interacts with the user in a technological product, or website. This may be the visual layout of a webpage. or the control buttons of a radio, designs of the User interface must not be only attractive to users but also must be created with users in mind and functional. Figures 7 and 8 show the registration interface and the products available for the customer to buy interface respectively.

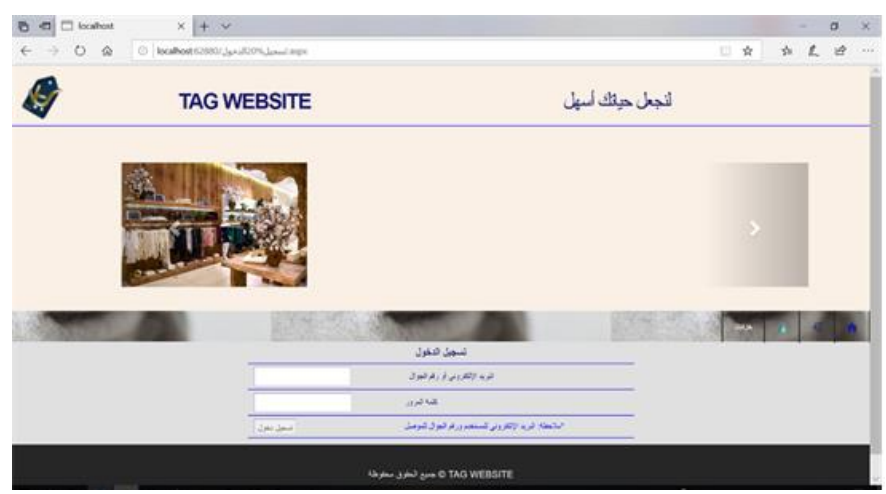

Figure 7: Registration interface.

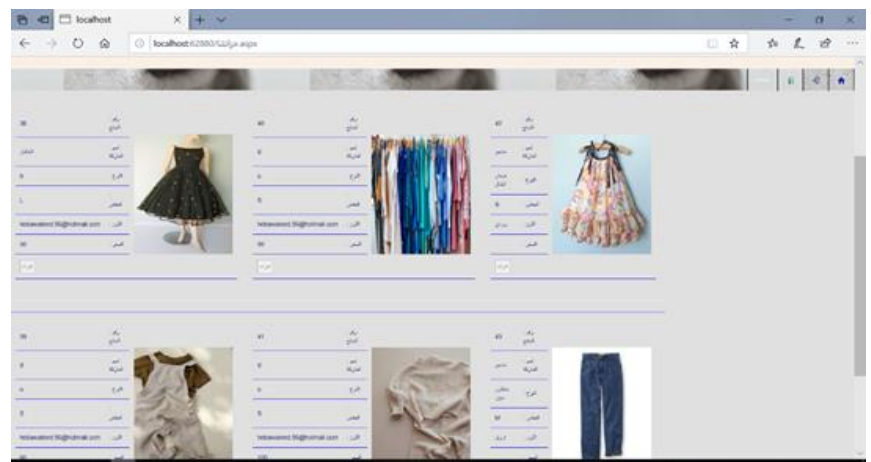

Figure 8: the products available for the customer to buy.

\section{DISCUSSION}

For evaluation purposes, 20 students were asked to test the prototype. They were given brief disruption about the usage of the prototype and the user interface. After that, they tested the system and responded to the questionnaire which consists of 10 items designed to measure the user's satisfaction level. The result and the usability level of the system according to the provided feedback by 20 students can be indicated in figure 9. As can be interpreted from the result, a high percentage of users agrees that system is useful, practical and fulfill the project's primary objective.

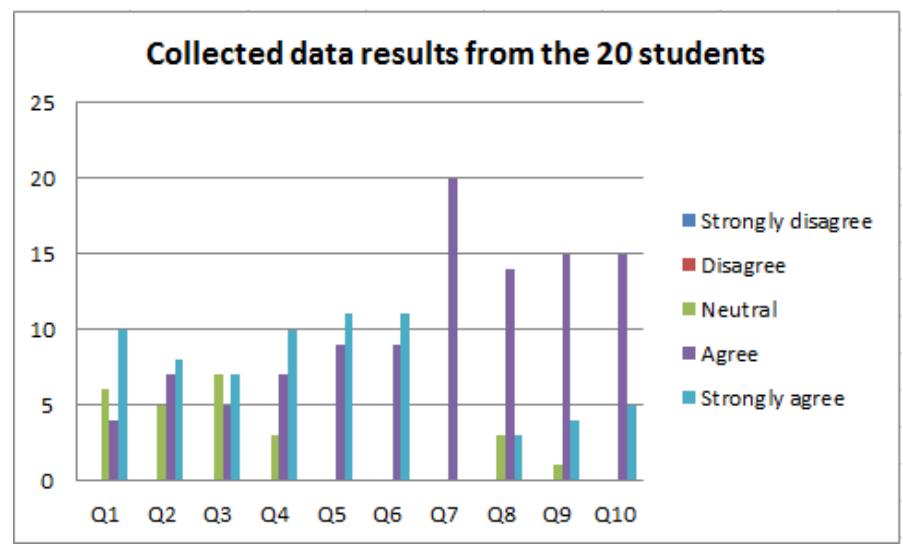

Figure 10: collected data results from the 20 students.

\section{CONCLUSION}

The main objective of our project is to achieve good interaction between the seller and buyer. And to 
make an easy marketing system and save time. In this work, a website of unused goods online shopping has been designed and implemented, the proposed online shopping website sells various fashions and goods to the customers, the goods that will be for sale on the website are new unused goods which the customer couldn't return to the store they buy from to any reason. The proposed system was developed using the Unified Modeling Language (UML), ASP.NET and Access.

\section{REFERENCES}

[1]. Li K, Huang X, Li Y and Feng Y. Design and Implementation of Tracing Shopping Guide System Based on Two Dimensional Code Lighting. In 2018 14th International Conference on Computational Intelligence and Security (CIS), pp. 325-329.

[2]. Hongfei Z and Zhimin L. Design and implementation of Online Shopping Mall for Children's Sports Products. China Computer \& Communication, 2018(7): 46.

[3]. Rabbi $M$ and Islam M. Design and Implementation of E-commerce Site for Online Shopping. 2019.

[4]. Megalingam R K, Vishnu S, Sekhar S, Sasikumar V, Sreekumar S and Nair T R. Design and Implementation of an Android Application for Smart Shopping. In 2019 International Conference on Communication and Signal Processing (ICCSP), pp. 0470-0474.

[5]. Vatrapu S R. Design and Implementation of ECommerce Site for Online Shopping. 2014.

[6]. Almarashdeh I and Alsmadi M K. How to make them use it? Citizens acceptance of $\mathrm{M}$ government. Applied Computing and Informatics.

[7]. Alsmadi M, Omar K, Noah S, Almarashdeh I, Al-Omari S, Sumari P, Al-Taweel S, Husain A, Al-Milli $\mathrm{N}$ and Alsmadi $\mathrm{M}$. Fish recognition based on robust features extraction from size and shape measurements using neural network. Information Technology Journal, 2009, 10(5): 427-434.

[8]. Alsmadi M, Omar K B and Noah S A. Back propagation algorithm: the best algorithm among the multi-layer perceptron algorithm. International Journal of Computer Science and Network Security, 2009, 9(4): 378-383.

[9]. Alsmadi M k, Omar K B and Noah S A. Proposed method to decide the appropriate feature set for fish classification tasks using Artificial Neural Network and Decision Tree. IJCSNS 2009, 9(3): 297-301.

[10]. Alsmadi M K S, Omar K B, Noah S A and Almarashdah I. Fish recognition based on the combination between robust feature selection, image segmentation and geometrical parameter techniques using Artificial Neural Network and Decision Tree. arXiv preprint arXiv:0912.0986, 2009.

[11]. khalil Alsmadi M, Omar K B, Noah S A and Almarashdah I. Performance comparison of multi-layer perceptron (Back Propagation, Delta Rule and Perceptron) algorithms in neural networks. In 2009 IEEE International Advance Computing Conference, pp. 296-299.

[12]. Almarashdeh I A, Sahari N, Zin N A M and Alsmadi M. THE SUCCESS OF LEARNING MANAGEMENT SYSTEM AMONG DISTANCE LEARNERS IN MALAYSIAN UNIVERSITIES. Journal of Theoretical \& Applied Information Technology, 2010, 21(2).

[13]. Almrashdah I A, Sahari N, Zin N A H M and Alsmadi M. Instructors acceptance of distance learning management system. In Information Technology (ITSim), $2010 \quad$ International Symposium in, pp. 1-6.

[14]. Almrashdah I A, Sahari N, Zin N A H M and Alsmadi M. Distance learners acceptance of learning management system. In Advanced 
Information Management and Service (IMS), 2010 6th International Conference on, pp. 304309.

[15]. Alsmadi M K, Omar K B and Noah S A. Fish recognition based on robust features extraction from size and shape measurements using backpropagation classifier. International Review on Computers and Software, 2010, 5(4): 489-494.

[16]. Alsmadi M K, Omar K B, Noah S A and Almarashdeh I. Fish recognition based on robust features extraction from color texture measurements using back-propagation classifier. Journal of Theoritical and Applied Information Technology, 2010, 18(1).

[17]. Alsmadi M K, Omar K B, Noah S A and Almarashdeh I. Fish recognition based on robust features extraction from size and shape measurements using neural network. Journal of Computer Science, 2010, 6(10): 1088.

[18]. Almarashdeh I A, Sahari N, Zin N A M and Alsmadi M. Acceptance of learning management system: A comparison between distance learners and instructors. Advances in Information Sciences and Service Sciences, 2011, 3(5): 1-9.

[19]. ALMRASHDEH I A, SAHARI N, ZIN N A M and ALSMADI $M$. DISTANCE LEARNING MANAGEMENT SYSTEM REQIUREMENTS FROM STUDENT'S PERSPECTIVE. Journal of Theoretical \& Applied Information Technology, 2011, 24(1).

[20]. Almrashdeh I A, Sahari N, Zin N A M and Alsmadi M. Instructor's success measures of Learning Management System. In Electrical Engineering and Informatics (ICEEI), 2011 International Conference on, pp. 1-7.

[21]. Almrashdeh I A, Sahari N, Zin N A M and Alsmadi M. Requirement analysis for distance learning management system students in Malaysian universities. Journal of Theoretical and Applied Information Technology, 2011, 24(1): 17-27.

[22]. Alsmadi M, Omar K, Noah S and Almarashdeh I. A hybrid memetic algorithm with backpropagation classifier for fish classification based on robust features extraction from PLGF and shape measurements. Information Technology Journal, 2011, 10(5): 944-954.

[23]. Alsmadi M K, Omar K B and Noah S A. Fish classification based on robust features extraction from color signature using back-propagation classifier. Journal of Computer Science, 2011, 7(1): 52.

[24]. Alsmadi M, Omar K and Almarashdeh I. Fish Classification: Fish Classification Using Memetic Algorithms with Back Propagation Classifier. 2012.

[25]. Alsmadi M, Badawi U A and Reffat H E. A High Performance Protocol for Fault Tolerant Distributed Shared Memory (FaTP). Journal of Applied Sciences, 2013, 13: 790-799.

[26]. Alsmadi M, Badawi U A, Reffat H E, Qiang S, Chanjian F, Yuegang $\mathrm{L}$ and Peng S. Faults Diagnosis for Automotive Engine Based on Chinin. Journal of Applied Sciences, 2013, 13(23): 5632.

[27]. Badawi U A and Alsmadi M K S. A Hybrid Memetic Algorithm (Genetic Algorithm and Great Deluge Local Search) With BackPropagation Classifier for Fish Recognition International Journal of Computer Science Issues, 2013, 10(2): 348-356.

[28]. Thalji $\mathrm{Z}$ and Alsmadi M. Iris Recognition using robust algorithm for eyelid, eyelash and shadow avoiding. World Applied Sciences Journal, 2013, 25(6): 858-865.

[29]. Alsmadi M K. A hybrid firefly algorithm with fuzzy-C mean algorithm for MRI brain segmentation. American Journal of Applied Sciences, 2014, 11(9): 1676-1691. 
[30]. Alsmadi M K, Badawi U A and Moharram H M. SERVER FAILURES ENABLED JAVASPACES SERVICE. Journal of Computer Science, 2014, 10(4): 671-679.

[31]. Badawi U A and Alsmadi M K. A GENERAL FISH CLASSIFICATION METHODOLOGY USING META-HEURISTIC ALGORITHM WITH BACK PROPAGATION CLASSIFIER. Journal of Theoretical \& Applied Information Technology, 2014, 66(3): 803-812.

[32]. Al Smadi A M, Alsmadi M K, Al Bazar H, Alrashed S and Al Smadi B S. Accessing Social Network Sites Using Work Smartphone for Face Recognition and Authentication. Research Journal of Applied Sciences, Engineering and Technology, 2015, 11(1): 56-62.

[33]. Alsmadi M K. MRI brain segmentation using a hybrid artificial bee colony algorithm with fuzzy-c mean algorithm. Journal of Applied Sciences, 2015, 15(1): 100.

[34]. HADDAD F, ALFARO J and ALSMADI M K. HOTELLING'S T $\mathrm{T}^{2} \quad$ CHARTS USING WINSORIZED MODIFIED ONE STEP MESTIMATOR FOR INDIVIDUAL NON NORMAL DATA. Journal of Theoretical \& Applied Information Technology, 2015, 72(2): 215-226.

[35]. Almarashdeh I and Alsmadi M. Investigating the acceptance of technology in distance learning program. In 2016 International Conference on Information Science and Communications Technologies (ICISCT), 2-4 Nov. 2016, pp. 1-5.

[36]. Almarashdeh I and Alsmadi M. Heuristic evaluation of mobile government portal services: An experts' review. In Internet Technology and Secured Transactions (ICITST), 2016 11th International Conference for, pp. 427-431.
[37]. Alsmadi M. Facial recognition under expression variations. Int. Arab J. Inf. Technol., 2016, 13(1A): 133-141.

[38]. Alsmadi M K. Forecasting River Flow in the USA Using a Hybrid Metaheuristic Algorithm with Back-Propagation Algorithm. Scientific Journal of King Faisal University (Basic and Applied Sciences), 2017, 18(1): 13-24.

[39]. Alsmadi M K. Query-sensitive similarity measure for content-based image retrieval using meta-heuristic algorithm. Journal of King Saud University - Computer and Information Sciences, 2017.

[40]. Alsmadi M K. An efficient similarity measure for content based image retrieval using memetic algorithm. Egyptian Journal of Basic and Applied Sciences, 2017, 4(2): 112-122.

[41]. Alsmadi M K and Badawi U A. Pattern matching in Rotated Images Using Genetic Algorithm. Journal of King Abdulaziz University Computing and Information 2017, 5: 53 - 59.

[42]. Alsmadi M K, Hamed A Y, Badawi U A, Almarashdeh I, Salah A, Farag T H, Hassan W, Jaradat G, Alomari $\mathrm{Y} \mathrm{M}$ and Alsmadi $\mathrm{H} \mathrm{M}$. FACE IMAGE RECOGNITION BASED ON PARTIAL FACE MATCHING USING GENETIC ALGORITHM. SUST Journal of Engineering and Computer Sciences (JECS), 2017, 18(1): 51-61.

[43]. Farag T H, Hassan W A, Ayad H A, AlBahussain A S, Badawi U A and Alsmadi M K. Extended Absolute Fuzzy Connectedness Segmentation Algorithm Utilizing Region and BoundaryBased Information. Arabian Journal for Science and Engineering, 2017: 1-11.

[44]. Aldaej R, Alfowzan L, Alhashem R, Alsmadi M K, Al-Marashdeh I, Badawi U A, Alshabanah M, Alrajhi D and Tayfour M. Analyzing, Designing and Implementing a Web-Based Auction online 
System. International Journal of Applied Engineering Research, 2018, 13(10): 8005-8013.

[45]. Almaimoni H, Altuwaijri N, Asiry F, Aldossary S, Alsmadi M, Al-Marashdeh I, Badawi U A, Alshabanah $\mathrm{M}$ and Alrajhi D. Developing and Implementing WEB-based Online Destination Information Management System for Tourism. International Journal of Applied Engineering Research, 2018, 13(10): 7541-7550.

[46]. Almarashdeh i, Alsmadi M K, Farag T, Albahussain A S, Badawi U A, Altuwaijri N, Almaimoni H, Asiry F, Alowaid S, Alshabanah M, Alrajhi D, Fraihet A A and Jaradat G. RealTime Elderly Healthcare Monitoring Expert System Using Wireless Sensor Network International Journal of Applied Engineering Research, 2018, 13(6): 3517-3523.

[47]. Almarashdeh I, Alsmadi M K, Jaradat G, Althunibat A, Albahussain S A, Qawqzeh Y, Badawi U A, Farag T and Eldaw K E. Looking Inside and Outside the System: Examining the Factors Influencing Distance Learners Satisfaction in Learning Management System Journal of Computer Science, 2018.

[48]. Almarashdeh I, Eldaw K E, AlSmadi M, Badawi U, Haddad F, Abdelkader O A, Jaradat G, Alkhaldi A and Qawqzeh Y. Search Convenience and Access Convenience: The Difference Between Website Shopping and Mobile Shopping. In International Conference on Soft Computing and Pattern Recognition, pp. 33-42.

[49]. Al-Marashdeh I, Jaradat G M, Ayob M, Abu-AlAish A and Alsmadi M. An Elite Pool-Based Big Bang-Big Crunch Metaheuristic for Data Clustering. Journal of Computer Science, 2018, 14(12): 1611-1626.

[50]. Alsmadi M K. Apparatus and method for lesions segmentation. 2018.

[51]. Alsmadi M K. Facial expression recognition. 2018.
[52]. Alsmadi M K. A hybrid Fuzzy C-Means and Neutrosophic for jaw lesions segmentation. Ain Shams Engineering Journal, 2018, 9(4): 697-706.

[53]. Alsmadi M K. Query-sensitive similarity measure for content-based image retrieval using meta-heuristic algorithm. Journal of King Saud University-Computer and Information Sciences, 2018, 30(3): 373-381.

[54]. Alsubaie N, Althaqafi N, Alradwan E, Al-Hazza F, Alsmadi M, Al-Marashdeh I, Badawi U A, Alshabanah M, Alrajhi D, Alsmadi S and Tayfour M. Analyzing and Implementing an Online Metro Reservation System. International Journal of Applied Engineering Research, 2018, 13(11): 9198-9206.

[55]. Daniyah Alkhaldi D A, Hajer Aldossary, Mutasem k. Alsmadi, Ibrahim Al-Marashdeh, Usama A Badawi, Muneerah Alshabanah, Daniah Alrajhi. Developing and Implementing Web-based Online University Facilities Reservation System. International Journal of Applied Engineering Research, 2018, 13(9): 6700-6708.

[56]. Haddad F and Alsmadi M K. Improvement of The Hotelling's T2 Charts Using Robust Location Winsorized One Step M-Estimator (WMOM). Journal of Mathematics (ISSN 10162526), 2018, 50(1): 97-112.

[57]. Rasmi M, Alazzam M B, Alsmadi M K, Almarashdeh I A, Alkhasawneh R A and Alsmadi S. Healthcare professionals' acceptance Electronic Health Records system: Critical literature review (Jordan case study). International Journal of Healthcare Management, 2018: 1-13.

[58]. Abbas A A, Alzayer K, Alkhaldi A, Alsmadi M k, Alshabanah M, Alrajhi D, Almarashdeh I and Tayfour M. Analyzing and Implementinga System For Reporting, Follow Up and Resolving of Complaints. International Research Journal 
of Engineering and Technology, 2019, 6(1): 1833-1842.

[59]. Ahmed A O, Ahmed M E, Mekebbaty M M E, Osman A M, Mohamed A S, Alhaj G M and Shidwan O S. Impact of Change Characteristics in Planning for Future Professional Career. International Journal of Applied Engineering Research, 2019, 14(20): 3869-3878.

[60]. Aldossary S, Althawadi A, Almotairy M, Alsmadi M k, Alrajhi D, Alshabanah M, AlMarashdeh I, Tayfour M and Aljamaeen R. ANALYZING, DESIGNING AND IMPLEMENTING A WEB-BASED COMMAND CENTER SYSTEM. International Research Journal of Engineering and Technology, 2019, 6(1): 1008-1019.

[61]. Al-Ghamdi A, Al Harbi D, Alarfaj N, Al Hajri A, Almarashdeh I, Alsmadi M, Alshabanah M and Alrajhi D. Developing and Implementing a Web-Based Platform for Skills and Knowledge Exchange. Int J Sci Res Sci Technol, 2019, 6(3): 562-573.

[62]. Al-Ghamdi A, Harbi D A, Alarfaj N, Hajri B A, Almarashdeh I, Alsmadi M k, Alshabanah M and Alrajhi D. Developing and Implementing a Web-Based Platform for Skills and Knowledge Exchange. International Journal of Scientific Research in Science and Technology (IJSRST), 2019, 6(3).

[63]. Alhafi R, Almutairi S, Alsultan N, Alsmadi M K, Alshabanah M, Alrajhi D and Almarashdeh I. EPayment and Transactions using QR Codes. 2019.

[64]. Alharbi S, Altamimi A, Al-Qahtani F, Aljofi B, Alsmadi M, Alshabanah M, Alrajhi D and Almarashdeh I. Analyzing and Implementing a Mobile Reminder System for Alzheimer's Patients. International Research Journal of Engineering and Technology, 2019, 6(2): 1-11.

[65]. Ali S A S, Eldaw K E H I, Alsmadi M K and Almarashdeh I. Determinants of deposit of commercial banks in Sudan: an empirical investigation (1970-2012). International Journal of Electronic Finance, 2019, 9(3): 230-255.

[66]. Almarashdeh I, Jaradat G, Abuhamdah A, Alsmadi M, Alazzam M B, Alkhasawneh R and Awawdeh I. The Difference Between Shopping Online Using Mobile Apps and Website Shopping: A Case Study of Service Convenience. International Journal of Computer Information Systems and Industrial Management Applications, 2019, 11: 151-160.

[67]. Al-Omairi D S, AlNasheri W H, Al-Qarni W Y, Almarashdeh I, Alsmadi M k, Alshabanah M and Alrajhi D. Developing and Implementing A Web-Based Recycling System For Protecting The Green Environment. International Journal of Software Engineering and Applications, 2019, 10(3): 59-72.

[68]. Alomari E, Alshammry M, Alhamil S, Alsmadi M, Alshabanah M, Alrajhi D, Almarashdeh I and Eljawad L. Analyzing, Designing and Implementing a Consulting Company for Management Information Systems. International Research Journal of Engineering and Technology, 2019, 6(2): 422-432.

[69]. Alomari E, Alshammry M, Alhamil S, Alsmadi M k, Alshabanah M, Alrajhi D, Almarashdeh I and Eljawad L. Analyzing, Designing and Implementing a Consulting Company for Management Information Systems. International Research Journal of Engineering and Technology 2019, 6(2): 422-432.

[70]. Al-Smadi A M, Alsmadi M K, Baareh A, Almarashdeh I, Abouelmagd $\mathrm{H}$ and Ahmed O S S. Emergent situations for smart cities: a survey. International Journal of Electrical \& Computer Engineering (2088-8708), 2019, 9(6): 4777-4787.

[71]. Alsmadi M K. Hybrid Genetic Algorithm with Tabu Search with Back-Propagation Algorithm for Fish Classification: Determining the Appropriate Feature Set. International Journal 
of Applied Engineering Research, 2019, 14(23): 4387-4396.

[72]. Alsmadi M K, Tayfour M, Alkhasawneh R A, Badawi U, Almarashdeh I and Haddad F. Robust feature extraction methods for general fish classification. International Journal of Electrical \& Computer Engineering (2088-8708), 2019, 9(6): 5192-5204.

[73]. Al-Theeb R, Al-Tami H, Al-Johani H, AlMutairi A, Al-Marashdeh I, Alsmadi M K, Alshabanah $\mathrm{M}$ and Alrajhi D. Developing and Implementing A System for Shipping Companies Comparison. IJSRST 2019, 6(4).

[74]. Alzamel H, Alshabanah $\mathrm{M}$ and Alsmadi $\mathrm{M}$. Point of Sale (POS) Network with Embedded Fingerprint Biometric Authentication. International Journal of Scientific Research in Science and Technology (IJSRST), 2019, 6(5): 95-111.

[75]. Eljawad L, Aljamaeen R, Alsmadi M K, AlMarashdeh I, Abouelmagd H, Alsmadi S, Haddad F, Alkhasawneh R A, Alzughoul M and Alazzam M B. Arabic Voice Recognition Using Fuzzy Logic and Neural Network. International Journal of Applied Engineering Research, 2019, 14(3): 651-662.

[76]. Haddad F, Alsmadi M K, Badawi U, Farag T, Alkhasawneh R, Almarashdeh I and Hassan W. Bivariate modified hotelling's $\mathrm{T}^{2}$ charts using bootstrap data. International Journal of Electrical \& Computer Engineering (20888708), 2019, 9(6): 4721-4727.

[77]. Mohammed A S S, Alhaj G M, Osman A M and Ahmed A O. The Effectiveness of the Decision Making of the Saudi Arabian Universities Applied Colleges' Faculties Boards and Departmental Councils. International Journal of Applied Engineering Research, 2019, 14(23): 4221-4227.

[78]. Osman A M, Ahmed A O, Eltahir M N, Mohamed A S, Shidwan O S and Ghada M.
Investigating the Causes of inflation in Saudi Arabia: An Application of Autoregressive Distributed Lag (ARDL) Model. International Journal of Applied Engineering Research, 2019, 14(21): 3980-3986.

[79]. Qawqzeh Y K, Otoom M M, Al-Fayez F, Almarashdeh I, Alsmadi M and Jaradat G. A Proposed Decision Tree Classifier for Atherosclerosis Prediction and Classification. IJCSNS, 2019, 19(12): 197.

[80]. Sheikh R A, Al-Assami R, Albahr M, Suhaibani M A, Alsmadi M k, Alshabanah M, Alrajhi D, Al-Marashdeh I, Alsmadi S, Abouelmagd $\mathrm{H}$ and Tayfour M. Developing and Implementing a Barcode Based Student Attendance System. International Research Journal of Engineering and Technology, 2019, 6(1): 497-506.

[81]. Alsmadi M K. Content-Based Image Retrieval Using Color, Shape and Texture Descriptors and Features. Arabian Journal for Science and Engineering, 2020: 1-14.

[82]. Alzaqebah M A, Alrefai N, Ahmed E, Jawarneh $S$ and Alsmadi M. Neighborhood search methods with Moth Optimization algorithm as a wrapper method for feature selection problems. International Journal of Electrical \& Computer Engineering, 2020, 10(4).

[83]. Qawqzeh Y K, Jaradat G, AlYousef A, AbuHamdah A, Almarashdeh I, Alsmadi M, Tayfour M, Shaker K and Haddad F. Applying the Big Bang-Big Crunch Metaheuristic to Large-sized Operational Problems. International Journal of Electrical and Computer Engineering, 2020, 10(3): 2484-2502.

[84]. Fontoura M, Pree W and Rumpe B. UML-F: A modeling language for object-oriented frameworks. In European Conference on Object-Oriented Programming, pp. 63-82.

[85]. Teixeira 1, Xambre A R, Figueiredo $J$ and Alvelos H. Analysis and design of a project management information system: practical case 
in a consulting company. In Cite this article as :

CENTERIS/ProjMAN/HCis, pp. 171-178.

[86]. Almarashdeh I, Elias N F, Sahari N and Zain N

A M. Development of an interactive learning management system for malaysian distance learning institutions. . Middle East Journal of Scientific Research, 14(11),

10.5829/idosi.mejsr.2013.14.11.2339, 2013 14(11): 1471-1479.

[87]. Rajagopal D and Thilakavalli K. A Study: UML for OOA and OOD. International Journal of Knowledge Content Development \& Technology, 2017, 7(2): 5-20.

Abeer S. Alkhalfan, Zainab W. Altheeb, Noor A. Alshamsi, Heba W. Alothman, Ibrahim Almarashdeh, Muneerah Alshabanah, Daniah Alrajhi, Mutasem K. Alsmadi , "Designing and Developing of E-Commerce Website for Unused New Goods Shopping ", International Journal of Scientific Research in Science and Technology (IJSRST), Online ISSN : 2395-602X, Print ISSN : 2395-6011, Volume 7 Issue 2, pp. 215-225, March-April 2020. Available at doi : https://doi.org/10.32628/IJSRST207233 Journal URL : http://ijsrst.com/IJSRST207233

[88]. Torchiano M, Scanniello G, Ricca F, Reggio G and Leotta M. Do UML object diagrams affect design comprehensibility? Results from a family of four controlled experiments. Journal of Visual Languages \& Computing, 2017, 41: 1021.

[89]. Bello S I, Bello R O, Babatunde A O, Olugbebi $\mathrm{M}$ and Bello B O. A University Examination Web Application Based on Linear-Sequential Life Cycle Model. 2017.

[90]. Almarashde I, Althunibat A and Fazidah El N. Developing a Mobile Portal Prototype for Egovernment Services. Journal of Applied Sciences, 2014, 14: 791-797.

[91]. Nora Alsubaie N A, Eman Alradwan, Fatima AlHazza, Mutasem Alsmadi, Ibrahim AlMarashdeh, Usama A Badawi, Muneerah Alshabanah, Daniah Alrajhi, Sanaa Alsmadi, Mohammed Tayfour. Analyzing and Implementing an Online Metro Reservation System. International Journal of Applied Engineering Research, 2018, 13(11): 9198-9206. 